\title{
Axiological aspects of social protection of individuals affected by radiation
}

\author{
Yulia Sergeyevna Cherepantseva* \\ Department of Labor Law and Social Security Law, Orenburg Institute (branch) University named after O. E. Kutafin (MSAL), \\ Orenburg, Russia
}

\begin{abstract}
The purpose of the research is determined by the value of human life, which has been recognized absolute since ancient times. Despite the fact that it does not depend on government activities, it is necessary to adopt measures to protect life and create conditions for this. The government should protect individuals by performing actions and ensuring their rights. One of the manifestations of protective actions is legislative consolidation of the right to life and health protection, whose implementation becomes the main measure aimed at compensating for the harm caused by the negative impact of radiation. Based on the analysis of the Russian legislation on social protection of citizens affected by radiation exposure, the axiological aspects of the legal measures are described. The understanding of human life and health as the highest value protected by law is in line with the constitutional principles and norms of international law. The author concludes about the importance of ensuring universality in the exercise of these rights under the negative impact of radiation caused by various factors in relation to all categories of victims. The research results can become the basis for further research on social security in improving the legislation and law enforcement practice.
\end{abstract}

\section{Introduction}

In the surrounding world, a person is trapped by various phenomena that influence him. Some of them are tangible; thanks to their senses, people can react, protecting themselves from their effects. Unfortunately, there are also such phenomena that cannot be recognized. One of these phenomena is radiation and its negative factors.

Radiation is an ancient environmental factor. There are many natural sources of radiation: the earth's crust, building materials, air, food and water, cosmic rays. Natural radiation is present in the bones and muscles of animals and humans, and radioactive substances present in the air enter the lungs. As soon as the exposure levels exceed acceptable limits, radiation and its intrinsic penetrating factors pose an immediate threat. The result of ionizing radiation is the mass death of body cells, malignant formations, genetic mutations, etc.

Consequently, the most unpleasant property of radiation is its penetration into the tissues of a living organism, due to which undesirable and destructive consequences manifest themselves. But the worst thing is that a person does not begin to feel this immediately.

The development of human civilization has led to the widespread use of nuclear and atomic energy in science, weapons, industries, energy, agriculture, medicine, transport. Nuclear energy has become an integral part of our life. Of course, its main purpose is to help in the diagnosis and treatment of diseases, to ensure normal human life. This is fully consistent with the goals proclaimed in the United Nations Declaration on the Prevention of Nuclear Catastrophe; according to paragraph 5, nuclear energy should be used only for peaceful purposes, for the benefit of mankind. The likelihood of radiation accidents is obvious. Radiation accidents occurred in different countries (USA, Switzerland, Canada, Russia, Ukraine, Japan). They violated normal conditions of life and created threats to human health and life.

Another modern manifestation of nuclear energy is nuclear weapons. The development and testing of atomic and nuclear weapons, which began after the end of World War II, led to their appearance in the arsenal of the world leading powers. At the international level, the United Nations realizes that all the horrors of past wars, other disasters would fade before the use of nuclear weapons capable of destroying the civilization. The countries which will use nuclear weapons can commit the gravest crime against humanity. To ensure the national security, it is necessary, nuclear weapons are required. Therefore, the ongoing tests of nuclear weapons should be put on a par with the factors leading to negative consequences.

Regardless of what caused the exposure to radiation an emergency at an industrial or production facility or planned testing of a new type of weapon - the result for a

Corresponding author: chus1973@mail.ru 
person is the same - harm. The risk of radiation exposure is always present.

The government has taken measures to compensate for the damage caused. At the same time, various methods are used: provision of monetary and other material benefits and compensation to citizens for damage to their health. However, given the significant time factor that determines the moment of radiation catastrophes, we can only talk about compensation for what happened. This necessitates the development of legal means to ensure timely support from and proper implementation of protective measures. The lack of independent comprehensive studies that determine the specifics of value aspects of social protection of the rights and interests of victims of radiation reduces the level of implementation of these rights.

\section{Materials and methods}

The analysis of Russian legislation on social protection of citizens exposed to radiation as a result of the Chernobyl disaster, the article describes legal measures aimed to protect the life and health of victims. Particular attention is paid to the protection of health of children and compensation for harm.

The influence of decisions of the Constitutional Court of the Russian Federation in determining the fundamental principles characterizing the legal position of the government on the issues of social protection of citizens affected by radiation is described.

International legal acts which pay special attention to the right to life and health protection are studied.

The author uses methods of analysis and synthesis of scientific and legal information, which made it possible to give an objective assessment of the current state of affairs in the area under consideration.

\section{Results}

Humans are exposed to radiation throughout their lives. Their bodies are subject to natural radioactivity, which is observed in natural processes. But the conditions of modern life have brought the factor of industrial use of atomic and nuclear energy to the fore. The unpredictability of the flow of technological processes, insufficient knowledge of the influencing factors inherent in radiation indicate that a person is not able to control this element. Due to man-made accidents, radiation causes negative consequences, expressed in the pollution of the natural environment and harm to human health and life.

Under the radiation exposure, the axiological aspects of protection of a person as a natural being are determined by his health and duration of life. This conclusion is based on the fact that it is the most vulnerable factor in the physical existence of a living organism. The danger of radiation exposure is connected with the impact of damaging factors inherent in radiation, which leads to the disruption of vital processes, causing illness or death.
Of course, health is not all life, but without a doubt, without it, a person's life loses all meaning. Human health and life are the main factors that were influenced by radiation exposure due to the disaster at the Chernobyl nuclear power plant, nuclear weapons tests at Totsk and Semipalatinsk test sites, and a mechanism for redressing the harm caused to these important concepts is determined.

Life and health are used in the meaning of objects of protection in almost all regulations governing both the handling of radiation sources and regulating protective and compensatory measures. Thus, it is emphasized that the relationship between a citizen who is harmed as a result of exposure to radiation and the state is in the plane of the latter assuming obligations to compensate for the damage, and the victim has the right to use this obligation.

The issue of compensation for life and health as an "absolute value" is complex. Leaving aside the aspects of morality, money paid for the injured or deceased breadwinner can save the family from economic difficulties. The price of life and health is a moral, economic and legal category.

Paradoxically, on the one hand, it is argued that life and health are priceless; on the other hand, society demonstrates that they have a low value. As a result, they are measured and expressed in money. The similar approach can be seen in the main regulations governing the issues of social protection of people affected by radiation, based on the material compensation concept of social support.

We can most clearly trace these aspects by analyzing the regulatory legal acts adopted in connection with the radiation catastrophe at the Chernobyl nuclear power plant. This predetermination is due to the fact that the gigantic experience that was gained as a result of work to eliminate its consequences has no equal in world practice. The real irreplaceability and incalculability of the harm caused by the accident at the Chernobyl nuclear power plant determined the choice of a special approach in restoring violated rights, the main of which is the right to life and health protection.

Having determined the principle of the maximum possible as a fundamental one, the Constitutional Court of the Russian Federation assessed the provision of monetary and other material benefits and compensation to citizens for damage to their health as the main method of compensation for harm. Emphasizing that it is difficult to objectively assess the harm caused, the conclusion has been drawn based on the recognition of the amount of compensation as ensuring the level of life in which their very right to compensation for harm and the principle of respect for the dignity of the individual would not be questioned.

The main factors expressing harm to health are diseases (among which the worst is cancer in its various manifestations, genetic mutations, especially in future generations), disability as a result of these, and, as a result, death. The problem today is that it is very problematic, and often impossible, to prove the fact of the radioactive effect on the human body and the negative changes that have occurred. To confirm such a 
causal relationship, the victims are forced to undergo a medical examination in specialized medical organizations. That is why judicial protection of the victims has become the main measure for the implementation of their rights enshrined in legislation.

Long-term experimental and epidemiological studies of radiation accidents have identified one of the most important problems - the study of the health status of participants in post-emergency work and the population affected by radiation. Its solution lies in the plane of medicine, where, unfortunately, there is also no consensus of opinion. For example, even the proclaimed non-threshold concept of the effect of radiation on a person and the manifestation of its consequences has recently been criticized, and the negative factors inherent in radiation are considered no longer causing any serious disturbances in a living organism, not leading to the development of serious diseases and not causing detrimental effect on future offspring. With that it is impossible to agree.

The understanding of human life as the highest value protected by law is reflected in the international legal acts. Proclaiming the equality from birth, article 3 of the Universal Declaration of Human Rights stipulate that "everyone has the right to life". Article 5 of the International Covenant on Economic, Social and Cultural Rights recognizes the right to life as an inalienable right protected by law. The European Convention on the Protection of Human Rights and Fundamental Freedoms also enshrines the right to life.

In Russia, this right was first formulated in the 1991 Declaration of the Rights and Freedoms of Man and Citizen. In the Constitution of the Russian Federation, the right to life is guaranteed by Article 20. It indicates the importance of human life and health in the legal system.

In modern conditions, the right to life is beyond doubt. This is due to the environment. This that affects the quality of life and is expressed in its duration. Therefore, the quality of life is determined by health indicators. A number of international documents, such as the UN Stockholm Declaration on the Human Environment of June 16, 1972, the UN Rio Declaration on Environment and Development of June 3-14, 1992, the 1982 World Charter for Nature and others reflect the right of every person to a healthy environment, which predetermines the healthy state of the human body.

Understanding health as a human right imposes legal obligations on states to ensure access to timely, acceptable and affordable health care of adequate quality, as well as to identify and guarantee the relevant determinants of health, which include safe drinking water and food, housing, health-related information, etc.

Russia as a social state that protects health of citizens fulfills its constitutional obligations, pays special attention to the protection of women and children. Legally, adults and children are classified as victims. This predetermined the universal nature of parental care for the health of children. With regard to persons exposed to radiation, the Constitutional Court of the Russian Federation determined that the legal status of a child is derived from the status of parents from the contaminated area. Consequently, children are among the persons entitled to reparations and social support measures. 35 years after, it is the children of the victims who become the main claimants for compensation for the harm caused.

Characterizing the axiological aspects, one should agree with the interpretation of the right to life as the right of every person to "full life", which implies the obligation of the government to promote the continuation of this life, since the highest value of life is the right of every person to leave behind offspring [1]. One of the directions in the implementation of protective measures is the extension of the right to social protection to children who were in intrauterine development at during the radiation accident at the Chernobyl nuclear power plant.

Considering that ionizing radiation affects the body of a pregnant woman, the fetus (embryo) is exposed to equal radiation exposure due to the biological connection with the mother's body. This inextricable link allowed the Constitutional Court to consolidate the principle of equality in the dissemination and application of measures to protect children who were in fetal development during the Chernobyl accident.

Taking into account the increased risk of fetal death, possible negative changes in physical or mental development, the main goal was to exclude or minimize negative consequences, both for the pregnant woman and ensuring the normal development of the fetus. As a result, equality was established in the exposure to radiation risk, the degree of exposure, and the legal status of a child in the intrauterine development. These conclusions of the Constitutional Court are fully consistent with the constitutional right to life, even though its legal protection is regulated since birth.

A comprehensive analysis of the problems of social protection from radiation exposure requires studies on the effectiveness of applied protective measures. An extraordinary catastrophe that resulted in incalculable environmental and humanitarian losses, the Chernobyl disaster provided a completely new perspective on what happened.

Taking into account the fact that the half-life of most radioactive elements that formed the dose load at the current moment has passed, it is not possible to return to the usual way of life in the affected territories. The longterm measures have intensified the psychological tension and aggravated socio-psychological problems. The psychosomatic symptoms experienced by the victims of the Chernobyl disaster are similar to the health problems in the survivors of the atomic bombings in Hiroshima and Nagasaki [2]. Radiophobia has become the most common form of mental illness in the Chernobyl regions.

The Chernobyl disaster formed a new society, a new culture. Having united both Russians, Ukrainians and Belarusians, the accident made them Chernobyl victims. "Chernobyl has become a source of similar problems: the lack of clean food, care for medicines and health improvement, illness, anxiety for the future of children, painful parting with their homeland and moving to a new place of residence" [3]. In sociology, the so-called 
"Chernobyl complex" has appeared. It is characterized by a feeling of insecurity, abandonment, opposition to other members of society. Studies proved that the understanding of damage from radiation disasters is reduced to material and physical losses [4]. The legislation does not take into account subjective factors of perception of radiation disasters.

The protective measures were perceived rather ambiguously. Benefits became a circumstance that hindered their relocation to clean areas, where there were employment problems.

\section{Discussion}

Articles 1, 2, 7, 20, 42 and 53 of the Constitution of the Russian Federation allow us to assert that the right to compensation for harm to life and health is a constitutional obligation of the Russian Federation as a social state predetermined by communication between the state, whose activities in the development and use of nuclear energy are associated with the infliction of harm, and citizens affected by these activities

In fulfilling this obligation, the legislator has developed a system of measures aimed at compensating for the harm caused by radiation. According to the Constitutional Court Resolution No. 17-P of November 10, 2009, the legal mechanism chosen for compensation is recognized as compensatory. In this case, damage is compensated for in a universal way, because government guarantees are possible only within the public law models that oblige the government to provide a citizen with social benefits and services in the manner and under the conditions established by law [5].

Social security law has a range of tools suitable for achieving protection objectives. Social security law is aimed at compensating negative consequences. Social security is always addressed to a person who is not able to fulfill his basic, socially significant needs at the expense of his own resources. It is provided to those who find themselves in a situation of social risk, when, due to objective reasons, they are unable to obtain income from their labor [6].

The main parameters of legal impact include conceptual aspects such as the value of life and health of all affected citizens; the most complete amount of compensation for harm as really irreparable and incalculable; proportionality of the goal and legal means used to achieve it; stability of the legal status of persons affected by radiation.

The procedure for compensating for the loss of life and health due to radiation exposure is complicated, because harm can be inflicted both at once and due to prolonged damaging factors. In the first case, the harm to health is obvious; with regard to long-term exposure to radiation, the solution is complicated, but in the current legislation it is associated with recognizing the affected territory a special zone. The universal approach to the recognition of the right to compensation for harm to life and health differs only in the level of guarantees of the rights of affected citizens.
The current social protection system for victims of the Chernobyl disaster indicates the underestimation of the axiological aspects. They are most clearly manifested in the ongoing reduction in the number of areas recognized as victims of radiation. Over the past 3 years, a significant part of the territories has been declared "clean" (only 4 infected regions of the Russian Federation). This decreased the number of people living in the contaminated territory (from 1.5 million to 600 thousand people) [7].

In addition, the territorial concept allows for a change in the established status. Protective measures have changed. For example, when the status of a zone with the right to resettlement changes and it is transferred to a zone with a preferential socio-economic status, residents do not have benefits.

And finally, this is the change in the conditions for the provision of benefits and implementation of social support measures. It is important to be aware of the inadmissibility of decreasing the established amount of compensation, prohibition of diminishing or limiting rights when improving the procedure and conditions for compensation for harm to health.

\section{Conclusions}

Human life and health are the highest social and legal benefits of the individual. In case of illness or death, all other human rights and freedoms lose their meaning. No state is able to bestow them as they are a gift of nature. The state is obliged to recognize, respect and protect in every way these values, which dominate others.

The development of mankind indicates that radiation has invaded the structure of conditions with which humans are interacting. In its worst manifestations, it poses a threat to the living environment. The main factor was the negative impact on the health of a huge number of people.

In order to compensate for the life and health of victims, the government has chosen a compensation mechanism. However, the practice of its application indicates the lack of an integrated approach in providing assistance to victims, since when compensating for harm, it is necessary to proceed from its material assessment and take into account the level and nature of moral damage.

Such an approach, based on maintaining high standards of a person as a biological and socio-economic entity, manifested in concern for his vital, material, and social values, will undoubtedly form a holistic and complete concept of assistance to victims, taking into account the most important value aspects.

It is indisputable that decisions should objective. All decisions should be based on the principle of equality in the value of life and health of all citizens. Differentiation is permissible only when differences are justified, and the legal means used to achieve these goals are proportionate to them. 


\section{References}

1. E.V. Perevozchikova, Constitutional right to life and human reproductive rights: thesis (Kazan, 2006) $137 \mathrm{p}$.

2. A. Metlyaeva, A.Yu. Bushmanov, V.I. Krasnyuk, O.V. Shcherbatykh, M.V. Bolotnov, Radiation and stress. Review of scientific publications on the human response to the effects of ionizing radiation, Medical Radiology and Radiation Safety, 5 (2016). Retrieved from: http: //www/medradiol.ru (date of access: 20.06.2021).

3. Y. Shevtsov, United Nation. The phenomenon of Belarus. Retrieved from: http://www.razlib.ru/politika/obedinennaja_nacija_f enomen_belorusii/index.php (date of access: 22/05/2021)
4. A.H. Barton, Communities in disaster: a sociological analysis of collective stress situations (New York, 1970) $352 \mathrm{p}$.

5. E.A. Istomina, M.Yu. Fedorova, Legal mechanism of social risk management: monograph (RANEPA, Yekaterinburg, 2018) $240 \mathrm{p}$.

6. M. Yu. Fedorova, Social value of labor and its formalization in social security law, Advances in Social Science, Education and Humanities Research, 498, 91-100 (2020). DOI: /https://doi.org/ 10.2991/assehr.k.201205.017

7. E. Skvortsova, The whole world is screaming that the sarcophagus is falling apart: what is happening in Chernobyl 35 years later. Retrieved from: https://sobesednik.ru/obshchestvo/20210426chernobylskij-reaktor-35-let-s (date accessed: 20.06.2021). 